\title{
HUBUNGAN INDEKS MASSA TUBUH TERHADAP INKONTINENSIA URIN TIPE STRES PADA WANITA USIA 45-60 TAHUN DI RSUD BANGLI
}

\author{
Komang Tri Adi Suparwati ${ }^{1}$, Ida Ayu Astiti Suadnyana ${ }^{2}$, I Putu Prisa Jaya ${ }^{3}$, \\ Made Ayu Meita Dewi Ananda ${ }^{4}$ \\ Program Studi Fisioterapi, Fakultas Ilmu-Ilmu Kesehatan, Universitas Bali Internasional \\ komangtriadisuparwati@iikmpbali.ac.id1, astitisuadnyana@iikmpbali.ac.id ${ }^{2}$
}

\begin{abstract}
Stress urinary incontinence is a health problem that is very common in women and is rarely complained of because it is considered something normal so it does not need to be treated. Stress urinary incontinence is a common problem in women with prevalence rates ranging from $10 \%$ to more than 40\%. The occurrence of stress urinary incontinence in women aged 45-60 years is influenced by several factors, one of which is body composition or body mass index. Heavy and excessive body mass index conditions will cause pressure on the bladder, resulting in the bladder more easily expelled urine inadvertently. This study aims to determine the relationship between body mass index and stress urinary incontinence in women aged 45-60 years. This research is a cross-sectional study. The sampling technique is non-probability sampling in the form of purposive sampling. The study was conducted at the Bangli Hospital in June-July 2021. The research sample amounted to 34 people. Body mass was measured by BMI and urinary incontinence was measured by RUIS (The Revised Urinary Incontinence Scale). Based on the Sommer'd test, $p$ value $=0.001(p<0.05)$ with a correlation coefficient value of 0.424 ( $r>0.05)$, which means that there is a significant relationship between body mass index and stress urinary incontinence in women aged 45-60 years.
\end{abstract}

Keywords $\quad$ : Stress Urinary Incontinence, Body Mass Index, Women

\begin{abstract}
ABSTRAK
Inkontinensia urin tipe stress merupakan masalah kesehatan yang sangat sering terjadi pada wanita dan jarang dikeluhkan karena dianggap sesuatu yang biasa sehingga tidak perlu diobati. Inkontinensia urin tipe stress adalah masalah umum pada wanita dengan tingkat prevalensi mulai dari $10 \%$ hingga lebih dari 40\%. Terjadinya inkontinensia urin tipe stress pada wanita usia 45-60 tahun ini dipengaruhi oleh beberapa faktor salah satunya adalah komposisi tubuh atau indeks massa tubuh. Kondisi indeks massa tubuh yang berat dan berlebihan akan menyebabkan penekanan pada kandung kemih, sehingga mengakibatkan kandung kemih lebih mudah mengalami pengeluaran urin secara tidak sengaja. Penelitian ini bertujuan untuk mengetahui hubungan indeks massa tubuh terhadap inkontinensia urin tipe stres pada wanita usia 45-60 tahun. Penelitian ini adalah cross-sectional study. Teknik pengambilan sampel non probability sampling dengan bentuk purposive sampling. Penelitian dilakukan di RSUD Bangli pada bulan Juni-Juli 2021. Sampel penelitian berjumlah 34 orang. Massa tubuh diukur dengan IMT dan inkontinensia urin diukur dengan RUIS (The Revised Urinary Incontinence Scale). Berdasarkan uji sommer'd didapatkan nilai $\mathrm{p}=0,001(\mathrm{p}<0,05)$ dengan nilai koefisien korelasi 0,424 $(r>0,05)$ yang artinya terdapat hubungan yang bermakna antara indeks massa tubuh terhadap inkontinensia urin tipe stress wanita usia 45-60 tahun.
\end{abstract}

Kata Kunci $\quad$ : Inkontinensia Urine Tipe Stres, Indeks Massa Tubuh, Wanita

\section{PENDAHULUAN}

Inkontinensia urin merupakan masalah kesehatan yang sangat sering terjadi pada wanita baik pada anak-anak, dewasa, maupun orang tua. Inkontinensia urin juga jarang dikeluhkan karena dianggap sesuatu yang biasa, malu atau tabu untuk diceritakan pada orang lain, sehingga dianggap sesuatu yang wajar tidak perlu diobati. Inkontinensia urin sendiri bukanlah suatu penyakit, tetapi merupakan gejala yang menimbulkan gangguan kesehatan, 
sosial, psikologi serta dapat menurunkan kualitas hidup.

Prevalensi inkontinensia urin pada wanita bervariasi, di dunia berkisar antara 10-58\%, sedang di Eropa dan Amerika berkisar antara 29,4\%. Menurut APCAB (Asia Pacific Continence Advisor Board) tahun 1998 menetapkan prevalensi inkontinensia urin $14,6 \%$ pada wanita Asia. Prevalensi di Asia relatif rendah karena pandangan orang Asia bahwa inkontinensia urin merupakan hal yang memalukan, sehingga tidak dikeluhkan pada dokter. Survei inkontinensia urin yang dilakukan oleh Departemen Urologi Fakultas Kedokteran Universitas Airlangga RSU Dr. Soetomo tahun 2008 terhadap 793 penderita, prevalensi inkontinensia urin pada pria $3,02 \%$ sedangkan pada wanita $6,79 \%$. Survei ini menunjukkan bahwa prevalensi inkontinensia urin pada wanita lebih tinggi daripada pria (Soetojo, 2009).

Inkontinensia urin adalah masalah umum pada wanita dengan tingkat prevalensi mulai dari $10 \%$ hingga lebih dari $40 \%$ tetapi hanya seperempat wanita dengan inkontinensia urin yang mencari pengobatan atau terapi (Maranon, 2017). Inkontinensia terbagi menjadi tiga tipe namun yang paling sering terjadi adalah inkontinensia urin tipe stres. Inkontinensia urin tipe stres mewakili sekitar 50\% kasus inkontinensia urin pada wanita. Inkontinensia urin tipe stres sekitar 10-20\% kasus dan inkontinensia urin campuran sekitar 30-35\% (Pomain dkk., 2016).

Faktor resiko terjadinya inkontinensia urin antara lain jenis kelamin wanita, usia lanjut/menopause, paritas tinggi, gangguan neurologis, kelebihan berat badan, perokok, minum alkohol, intake cairan berlebihan atau kurangnya aktifitas. Kelebihan berat badan menjadi salah satu faktor penyebab terjadinya inkontinensia urin, karena beban kerja dasar panggul pada orang-orang gemuk lebih besar daripada orang yang kurus (Soetojo, 2009). Orang dengan berat badan berlebih mengalami penumpukan beban di daerah abdomen. Beban tersebut akan memberi penekanan pada kandung kemih, sehingga mengakibatkan kandung kemih lebih mudah mengalami pengeluaran urin secara tidak sengaja (Scott, 2009). Selain itu, disebutkan pula bahwa terdapat hubungan yang signifikan antara penurunan berat badan dengan perubahan tekanan kandung kemih pada orang dengan kelebihan berat badan. Penurunan berat badan ini menyebabkan tekanan terhadap kandung kemih akan menjadi lebih rendah (Subak dkk., 2005). Penelitian yang dilakukan oleh Melville dkk., (2005) menyatakan bahwa prevalensi inkontinensia urin lebih tinggi terjadi pada wanita dan meningkat dengan bertambahnya usia, BMI, riwayat histerektomi, monopause, status depresi dan paritas.

Berdasarkan pemarapan masalah diatas bahwa pentingnya indeks massa tubuh pada wanita usia 45-60 tahun serta hubungannya dengan inkontinensia urin tipe stress pada wanita usia 45-60 tahun, yang dimana tujuan dari penelitian ini adalah untuk mengetahui hubungan indeks massa tubuh terhadap inkontinensia urin tipe stres pada wanita usia 45-60 tahun.

\section{METODE}

Penelitian ini merupakan penelitian dengan pendekatan cross-sectional study. Populasi target dalam penelitian ini adalah wanita usia 45-60 tahun di RSUD Bangli. Populasi terjangkau dalam penelitian ini adalah wanita 45-60 tahun yang memiliki indeks massa tubuh underweight, normal, overweight, dan obesitas di RSUD Bangli yang dimana penelitian ini dilakukan pada bulan Juni-Juli 2021 yang telah memenuhi kriteria inklusi dan eksklusi.

Teknik penentuan jumlah sampel dalam penelitian ini adalah non probability sampling dengan bentuk purposive sampling. Sesuai dengan kriteria inklusi dan eksklusi didapatkan 34 sampel. Alat ukur yang dipergunakan dalam penelitian ini adalah RUIS dan IMT. RUIS dapat digunakan untuk menilai inkontinensia urin yang dimana The Revised Urinary 
Incontinence Scale (RUIS) berisi lima skala item yang diambil dari Urogenital Distress Inventory-6 (UDI-6) dan Incontinence Severity Index (ISI) dengan reliabilitas konsistensi internal adalah Cronbach's alpha $(\alpha)=0,73-0,91$ (Sansoni dkk., 2011), sedangkan IMT dapat digunakan untuk menilai massa tubuh dengan nilai sensitivitas $(51,6 \%-72 \%)$ dan spesifisitas $(44,8 \%-77,7 \%)$.

\section{HASIL}

\section{Karakteristik Responden}

Adapun karakteristik responden dalam penelitian ini berdasarkan usia, indeks massa tubuh, dan inkontinensia urine tipe stress dapat dilihat pada tabel berikut ini :

Tabel 1. Karakteristik Responden Berdasarkan Usia

\begin{tabular}{ccc}
\hline Usia (thn) & $\mathrm{f}$ & $\%$ \\
\hline $45-50$ & 24 & 70,6 \\
$51-55$ & 8 & 23,5 \\
$56-60$ & 2 & 5,9 \\
\hline Jumlah & 34 & 100 \\
\hline
\end{tabular}

Pada table 1, menunjukkan bahwa responden pada usia 45-50 tahun yaitu sebanyak 24 orang $(70,6 \%)$, responden usia 51-55 tahun sebanyak 8 orang $(23,5 \%)$, dan responden usia 56-60 tahun sebanyak 2 orang $(5,9 \%)$.
Tabel 2. Karakteristik Responden Berdasarkan Indeks Massa Tubuh

\begin{tabular}{ccc}
\hline IMT & $\mathrm{f}$ & $\%$ \\
\hline Underweight & 2 & 5,9 \\
Normal & 13 & 38,2 \\
Overweight & 8 & 23,5 \\
Obesitas & 11 & 32,4 \\
\hline Jumlah & 34 & 100 \\
\hline tabel & menunjukkan
\end{tabular}

Pada tabel 2, menunjukkan bahwa responden berdasarkan Indeks Massa Tubuh, dimana untuk kategori underweight sebanyak 2 responden $(5,9 \%)$, kategori normal sebanyak 13 responden $(38,2 \%)$, kategori overweight sebanyak 8 responden $(23,5 \%)$ dan kategori obesitas sebanyak 11 respoden $(32,4 \%)$.

Tabel 3. Karakteristik Responden Berdasarkan Inkontinensia Urin Tipe Stres

\begin{tabular}{ccc}
\hline RUIS & $\mathrm{f}$ & $\%$ \\
\hline Urin Ringan & 10 & 29,4 \\
Urin Sedang & 14 & 41,2 \\
Urin Berat & 10 & 29,4 \\
\hline Jumlah & 34 & $100 \%$ \\
\hline
\end{tabular}

Pada tabel 3, menunjukkan bahwa responden berdasarkan Inkontinensia Urin Tipe Stress, dimana untuk kategori urin ringan sebanyak 10 responden $(29,4 \%)$, kategori urin sedang sebanyak 14 responden $(41,2 \%)$ dan kategori urin berat sebanyak 10 respoden $(29,4 \%)$.

Tabel 4. Tabel Silang Usia dan Inkontinensia Urin Tipe Stres

\begin{tabular}{|c|c|c|c|c|c|c|c|c|}
\hline \multirow{3}{*}{ Usia (thn) } & \multicolumn{6}{|c|}{ RUIS } & \multirow{2}{*}{\multicolumn{2}{|c|}{ Total }} \\
\hline & \multicolumn{2}{|c|}{ Ringan } & \multicolumn{2}{|c|}{ Sedang } & \multicolumn{2}{|c|}{ Berat } & & \\
\hline & $\mathrm{F}$ & $\%$ & $\mathrm{~F}$ & $\%$ & $\mathrm{~F}$ & $\%$ & $\mathrm{~N}$ & $\%$ \\
\hline $45-50$ & 10 & 100 & 8 & 57,1 & 6 & 60 & 24 & 70,6 \\
\hline $51-55$ & 0 & 0 & 6 & 42,9 & 2 & 23,5 & 8 & 23,5 \\
\hline $56-60$ & 0 & 0 & 0 & 0 & 2 & 5,9 & 2 & 5,9 \\
\hline Jumlah & 10 & 100 & 14 & 100 & 10 & 100 & 34 & 100 \\
\hline
\end{tabular}

Pada tabel 4, menunjukkan bahwa responden pada usia 45-50 tahun memiliki kategori inkontinensia urin tipe stress derajat ringan sebanyak 10 orang $(100 \%)$, derajat sedang sebanyak 8 orang $(57,1 \%)$ dan derajat berat sebanyak 6 orang $(60 \%)$. Responden pada usia 51-55 tahun memiliki kategori inkontinensia urin tipe stress derajat ringan sebanyak 0 orang $(0 \% 0$, derajat sedang sebanyak 6 orang $(42,9 \%)$, dan derajat berat sebanyak 2 orang $(23,5 \%)$. Responden pada usia 56-60 tahun memiliki kategori inkontinensia urin tipe stress derajat ringan sebanyak 0 orang $(0 \%)$ derajat sedang sebanyak 0 orang $(0 \%)$ dan derajat berat sebanyak 2 orang $(5,9 \%)$. 
Tabel 5. Tabel Silang Usia dan Indeks Massa Tubuh

\begin{tabular}{ccccccccccc}
\hline \multirow{2}{*}{ Usia (thn) } & \multicolumn{9}{c}{$\begin{array}{c}\text { Under } \\
\text { weight }\end{array}$} & \multicolumn{2}{c}{ Normal } & \multicolumn{2}{c}{ Over weight } & \multicolumn{2}{c}{ Obesitas } & & Total \\
\cline { 2 - 14 } & $\mathrm{F}$ & $\%$ & $\mathrm{~F}$ & $\%$ & $\mathrm{~F}$ & $\%$ & $\mathrm{~F}$ & $\%$ & $\mathrm{~N}$ & $\%$ \\
\hline $45-50$ & 2 & 5,9 & 10 & 29,4 & 5 & 14,7 & 7 & 20,6 & 24 & 70,6 \\
\hline $51-55$ & 0 & 0 & 2 & 5,9 & 3 & 8,8 & 3 & 8,8 & 8 & 23,5 \\
\hline $56-60$ & 0 & 0 & 1 & 2,9 & 0 & 0 & 1 & 0 & 2 & 5,9 \\
\hline Jumlah & $\mathbf{2}$ & $\mathbf{5 , 9}$ & $\mathbf{1 3}$ & $\mathbf{3 8 , 2}$ & $\mathbf{8}$ & $\mathbf{2 3 , 5}$ & $\mathbf{1 1}$ & $\mathbf{3 2 , 4}$ & $\mathbf{3 4}$ & $\mathbf{1 0 0}$ \\
\hline
\end{tabular}

Pada tabel 5, menunjukkan bahwa responden pada usia 45-50 tahun memiliki IMT dengan kategori underweight sebanyak 2 responden $(5,9 \%)$, kategori normal sebanyak 10 responden $(29,4 \%)$, kategori overweight sebanyak 5 responden $(14,7 \%)$ dan kategori obesitas sebanyak 7 responden (10,6\%). Pada usia 51-55 tahun memiliki IMT dengan kategori underweight sebanyak 0 responden $(0 \%)$, kategori normal sebanyak 2 responden
$(5,9 \%)$, kategori overweight sebanyak 3 responden $(8,8 \%)$ dan kategori obesitas sebanyak 3 responden $(8,8 \%)$. Sedangkan pada usia 56-60 tahun memiliki IMT dengan kategori underweight sebanyak 0 responden $(0 \%)$, kategori normal sebanyak 1 responden $(2,9 \%)$, kategori overweight sebanyak 0 responden $(0 \%)$ dan kategori obesitas sebanyak 0 responden $(0 \%)$.

\section{Hubungan antara Indeks Massa Tubuh (IMT) terhadap Inkontinensia Urin Tipe Stres}

Tabel 6. Tabel Silang Indeks Massa Tubuh (IMT) dan Inkontinensia Urin Tipe Stres

\begin{tabular}{|c|c|c|c|c|c|c|c|c|c|}
\hline \multirow{3}{*}{ IMT } & \multicolumn{6}{|c|}{ RUIS } & \multicolumn{2}{|c|}{ Total } & \multirow{3}{*}{ Nilai p } \\
\hline & \multicolumn{2}{|c|}{ Ringan } & \multicolumn{2}{|c|}{ Sedang } & \multicolumn{2}{|c|}{ Berat } & \multirow[b]{2}{*}{$\mathbf{N}$} & \multirow[b]{2}{*}{$\%$} & \\
\hline & $\mathbf{F}$ & $\%$ & $\mathbf{F}$ & $\%$ & $\mathbf{F}$ & $\%$ & & & \\
\hline Under weight & 0 & 0,0 & 2 & 5,9 & 0 & 0,0 & 2 & 5,9 & \multirow{5}{*}{0,001} \\
\hline Normal & 10 & 29,4 & 2 & 5,9 & 1 & 2,9 & 13 & 38,2 & \\
\hline Over weight & 0 & 0,0 & 1 & 2,9 & 7 & 20,6 & 8 & 23,5 & \\
\hline Obesitas & 0 & 0,0 & 9 & 26,5 & 2 & 5,9 & 11 & 32,4 & \\
\hline Jumlah & 10 & 29,4 & 14 & 41,2 & 10 & 29,4 & 34 & 100 & \\
\hline
\end{tabular}

Pada tabel 6, menunjukkan bahwa responden pada IMT dengan kategori underweight memiliki inkontinensia urin sedang sebanyak 2 responden $(5,9 \%)$ dan tidak ada responden pada inkontinensia urine ringan dan berat. Pada IMT dengan kategori normal memiliki inkontinensia urin ringan sebanyak 10 responden $(29,4 \%)$, inkontinensia urin sedang sebanyak 2 responden $(5,9 \%)$ dan inkontinensia urin berat sebanyak 1 responden (2,9\%). Pada IMT dengan kategori overweight memiliki inkontinensia urin berat sebanyak 7 responden $(20,6 \%)$, inkontinensia urin sedang sebanyak 1 responden $(2,9 \%)$, dan tidak ada responden pada inkontinensia urin ringan. Pada IMT dengan kategori obesitas memiliki inkontinensia urin sedang sebanyak 9 responden $(26,5 \%)$, inkontinensia urin berat sebanyak 2 responden $(5,9 \%)$, dan tidak ada responden untuk inkontinensia urin ringan.

\section{PEMBAHASAN}

\section{Karakteristik Responden}

Pada karakteristik berdasarkan usia menunjukkan bahwa, responden terbanyak 
pada kelompok usia 45-50 tahun yaitu sebanyak 24 responden, selanjutnya pada kelompok usia 51-55 tahun sebanyak 8 responden, dan pada kelompok usia 56-60 tahun sebanyak 2 responden, dimana total keseluruhan responden berjumlah 34 orang. Berdasarkan Indeks Massa Tubuh menunjukkan bahwa, responden terbanyak pada katerogi normal yaitu 13 responden, selanjutnya pada kategori obesitas sebanyak 11 responden, kategori overweight sebanyak 8 responden dan kategori underweight sebanyak 2 responden. Sedangkan berdasarkan inkontinensia urin tipe stress menunjukkan bahwa, responden terbanyak pada kategori inkontinensia urin sedang yaitu 14 responden, sedangkan untuk kategori inkontinensia urin ringan dan inkontinensia urin berat masing-masing sebanyak 10 responden.

Dari hasil penelitian melalui tabel silang antara usia dan inkontinensia urin tipe stress didapatkan hasil bahwa pada usia 45-50 tahun lebih banyak mengalami inkontinensia urin ringan sebanyak 10 responden, diikuti inkontinensia urin sedang sebanyak 8 responden, dan inkontinensia urin berat sebanyak 6 orang. Pada usia 51-55 tahun lebih banyak mengalami inkontinensia urin sedang sebanyak 6 responden, dan inkontinensia urin berat sebanyak 2 responden. Sedangkan pada usia 56-60 tahun lebih banyak mengalami inkontinensia urin berat sebanyak 2 responden.

Inkontinensia urin tipe stres akan semakin meningkat seiring dengan peningkatan usia (Luber, 2004). Menurut Akkus \& Pinar (2016), usia adalah faktor yang paling sering dikaitkan dengan inkontinensia urin. Perubahan usia pada wanita juga mempengaruhi hormon estrogen yang dimana estrogen dapat menurunkan konsentrasi kolagen total dan ikatan silang kolagen serta meningkatkan pergantian kolagen di jaringan peri-uretra sehingga tonus otot berkurang secara progresif yang diikuti dengan penurunan kontraktilitas (Ahn dkk., 2011).
Dari hasil penelitian melalui tabel silang antara usia dan Indeks Massa Tubuh didapatkan hasil bahwa pada usia 45-50 tahun lebih banyak mengalami indeks massa tubuh kategori normal sebanyak 10 responden, kategori obesitas sebanyak 7 responden, kategori overweight sebanyak 5 responden dan kategori underweight sebnyak 2 responden. Pada usia 51-55 tahun kondisi indeks massa tubuh lebih banyak dalam kategori overweight dan obesitas yang masing-masing sebanyak 3 responden, sedangkan kategori normal sebanyak 2 responden dan tidak ada responden dalam kategori underweight. Pada usia 56-60 tahun kondisi indeks massa tubuh cenderung mengarah ke kategori normal dan obesitas yang masing-masing sebanyak 1 responden dan tidak ada responden untuk kategori underweight dan overweight.

Komposisi lemak tubuh perempuan dua kali lebih besar dari laki-laki, dimana terjadi peningkatan dari $16-18 \%$ pada usia pra-remaja menjadi $23 \%$ pada usia remaja (Widyaningtyas, 2012). Seiring dengan bertambahnya usia maka kalori yang berlebih akan diubah menjadi lemak sehingga mengakibatkan bertambahnya berat badan, kebutuhan zat gizi karbohidrat dan lemak umumnya lebih rendah karena adanya penurunan metabolisme basal. Proses metabolisme yang menurun seiring dengan bertambahnya usia akan beresiko mengakibatkan kegemukan karena terjadi penurunan aktivitas fisik, maka kalori yang berlebih akan diubah menjadi lemak sehingga mengakibatkan kegemukan (Somantri, 2015).

\section{Hubungan antara Indeks Massa Tubuh (IMT) terhadap Inkontinensia Urin Tipe Stres}

Hasil uji analisis data menggunakan sommer'd diperoleh nilai $\mathrm{p}=0,001$ $(\mathrm{p}<0,05)$ dan kekuatan hubungan sebesar 0,424 . Dengan demikian indeks massa tubuh dengan inkontinensia urin tipe stres memiliki suatu hubungan yang signifikan dengan kekuatan hubungan yang moderate. 
Dari hasil penelitian didapatkan bahwa wanita dengan berat badan normal cenderung mengalami inkontinensia urin ringan yakni sejumlah 38 responden $(29,4 \%)$, sedangkan wanita dengan berat badan overweight dan obesitas cenderung mengalami inkontinensia urin tipe stress kategori sedang dan berat dengan 9 responden $(26,5 \%)$ inkontinensia urin sedang dan 7 responden $(20,6 \%)$ inkontinensia urin berat. Hal ini sesuai dengan teori bahwa wanita dengan berat badan overweight dan obesitas memiliki resiko lebih besar untuk mengalami inkontinensia urin.

Dalam penelitian yang dilakukan oleh Ulfah (2016), menyatakan bahwa terdapat beberapa alasan mengapa peningkatan IMT dikaitkan dengan inkontinensia urin, salah satunya yaitu semakin tinggi IMT seseorang maka akan diikuti peningkatan tekanan intra abdomennya yang semakin tinggi. Peningkatan ini akan semakin menekan otot dasar panggul sehingga menyebabkan menurunnya kemampuan pengendalian uretra dan kandung kemih. Pada keadaan ini besarnya peningkatan tekanan intra abdomen mampu untuk menekan urin ke uretra menjadi sangat mudah sehingga terjadinya kebocoran. Hal ini didukung oleh penelitian yang dilakukan oleh Pomain dkk., (2016) menyatakan bertambahnya indeks massa tubuh akan mengakibatkan tekanan yang lebih tinggi pada kandung kemih dan menyebabkan terjadinya mobilitas yang lebih besar (hipermobilitas) pada uretra. Mekanisme perkembangan stres inkontinensia urin yang paling mungkin terjadi pada wanita dengan berat badan berlebih adalah peningkatan tekanan intra abdomen yang menyebabkan melemahnya otot dasar panggul dan fasia. Pada penelitian yang dilakukan oleh Khullar dkk., (2014) menyatakan bahwa terdapat perbedaan yang signifikan ditemukan untuk rata-rata IMT dan kategori IMT di seluruh subkelompok inkontinensia urin. Nilai ratarata IMT yang lebih tinggi diamati pada stres inkontinensia urin.
Wanita dengan kondisi indeks massa tubuh yang overweight dan obesitas akan memberikan beban yang semakin besar sehingga dapat meningkatkan tekanan intra abdomen dan meningkatkan tekanan pada kandung kemih serta otot dasar panggul (Noblett dkk., 1997; Danforth, 2006). Secara normal uretra pada wanita memiliki panjang kurang lebih $4 \mathrm{~cm}$, dengan adanya kondisi indeks massa tubuh yang overweight dan obesitas akan menyebabkan peningkatan tekanan intra abdomen dan uretra pada wanita akan cendering mengalami pemendekan serta mobilitas lebih tinggi dan tonus otot akan menjadi semakin lemah. Sehingga hal tersebut mampu meningkatkan terjadinya inkontinensia urin (Greer, 2008).

Wanita dengan kondisi indek massa tubuh yang overweight dan obesitas akan cenderung lebih banyak mengalami inkontinensia urin (Swanson dkk., 2005). Inkontinensia urin yang paling sering dialami oleh wanita dengan kondisi indeks massa tubuh yang overweight dan obesitas adalah inkontinensia urin tipe stres, hal ini disebabkan karena beban yang berlebih menimbulkan peningkatan tekanan intra abdomen sehingga mempengaruhi otot dasar panggul dan meningkatkan mobilitas uretra. Namun inkontinensia urin tipe urgensi pun dapat terjadi dengan mekanisme adanya ketidakstabilan otototot detrusor akibat peningkatan tekanan intraabdomen sehingga pasien sering merasa ingin buang air kecil. Kedua tipe inkontinensia ini dapat ditemukan secara bersamaan atau digolongkan inkontinensia tipe campuran (Swanson, 2005; Subak dkk., 2005).

Hasil uji analisis data didapatkan indeks massa tubuh dengan inkontinensia urin tipe stres memiliki suatu hubungan yang signifikan dengan kekuatan hubungan yang moderate. Hal ini terjadi karena inkontinensia urin lebih banyak di temukan pada wanita usia lanjut dengan adanya penurunan kadar estrogen sehingga mempengaruhi perubahan morfologi dan fisiologi pada kandung kemih dan uretra, 
serta pada dinding kandung kemih terjadi peningkatan fibrosis dan kandungan kolagen sehingga fungsi kontraktil tidak efektif lagi. Atrofi mukosa, perubahan vaskularisasi submukosa, dan menipisnya lapisan otot uretra mengakibatkan menurunnya tekanan penutupan uretra (Setiati dan Pramantara, 2007). Dalam penelitian ini sample yang digunakan adalah wanita dengan usia 45-60 tahun dimana pada usia tersebut wanita memasuki masa pra menopause, sehingga wanita dalam sampel ini yang memiliki rentang usia 45-55 tahun masih memiliki pengaruh kuat dari hormon estrogen.

\section{KESIMPULAN}

Berdasarkan tujuan dan hasil dari penelitian didapatkan kesimpulan terdapat hubungan indeks massa tubuh terhadap inkontinensia urin tipe stress pada wanita usia 45-60 tahun di RSUD Bangli.

\section{UCAPAN TERIMA KASIH}

Ucapan terima kasih disampaikan kepada Direktur RSUD Bangli dan karyawan RSUD Bangli yang telah bersedia membantu dalam proses penelitian ini, serta teman-teman dosen dan mahasiswa prodi Fisioterapi Fakultas IlmuIlmu Kesehatan Universitas Bali Internasional yang turut membantu dan memberikan banyak masukan dalam menyelesaian penelitian ini.

\section{DAFTAR PUSTAKA}

Akkus, Y., \& Pinar, G. 2016. Evaluation of the prevalence, type, severity, and risk factors of urinary incontinence and its impact on quality of life among women in Turkey. International

urogynecology journal,27(6), $887-893$. DOI $10.1007 / \mathrm{s} 00192-$ 015-2904-5.

Ahn, K. H., Kim, T., Hur, J. Y., Kim, S. H., Lee, K. W., \& Kim, Y. T. 2011.
Relationship between serum estradiol and follicle-stimulating hormone levels and urodynamic results in women with stress urinary incontinence. International urogynecology journal,22(6), 731-737. DOI 10.1007/s00192011-1359-6

Danforth KN, Townsend MK, Lifford K, Curhan GC, Resnick NM, Grodstein F. Risk factors for urinary incontinence among middle-aged women. Am J Obstet Gynecol. 2006 Feb;194(2):33945. doi: 10.1016/j.ajog.2005.07.051.

PMID: 16458626; PMCID: PMC1363686.

Greer W.J., Richter H.E., Bartolucci A.A., Burgio K.L. 2008. Obesity and Pelvic Floor Disorder. Obstetrics and Gynecology. Vol 112(2): 341.

Khullar, V., Sexton, C. C., Thompson, C. L., Milsom, I., Bitoun, C. E., \& Coyne, K. S. 2014. The relationship between BMI and urinary incontinence subgroups: results from

EpiLUTS. Neurourology and urodynamics, 33(4), 392-399. DOI: $10.1002 /$ nau.22428.

Luber K.M. 2004. The Definition, Prevalence, and Risk Factor for Stress Urinary Incontinence. Review in Urology. Vol 6(3): S67

Marañón, J. A. 2017. Urinary Incontincence: Clinical Approach, Psychosocial and Contextual Factors. Gynecol Reprod Health, 1(4), 1-2.

Melville, J.L., Katon Wayne, Delaney Kristin, Newton K. 2005. Urinary Incontinence in USA Woman. 165 : 537-542

Noblett KL, Jensen JK, Ostergard DR. 1997. The relationship of body mass index to intraabdominal pressure as measured by 
multichannel cystometry. Int Urogynecol $J$ Pelvic Floor Dysfunct PubMed 9609328. Vol 8:323-6.

Pomian, A., Lisik, W., Kosieradzki, M., \& Barcz, E. 2016. Obesity and pelvic floor disorders: a review of the literature. Medical science monitor: international medical journal of experimental and clinical research, 22, 1880. DOI: 10.12659/MSM.896331

Sansoni, J. E., Hawthorne, G., Marosszeky, N., Moore, K. H., Fleming, G., \& Owen, E. A. 2011. Validation and clinical translation of the revised continence and patient satisfaction tools. Australian Health Services Research Institute

Scott J.R. 2009. Health Risks of Obesity: Incontinence.

http://weightloss.about.com/od/ob esityhealth/a/inconinence.htm.

Setiati Siti dan Pramantara I Dewa P. 2007. Inkontinensia Urin dan Kandung Kemih Hiperaktif. Dalam : Aru W. Sudoyo, Bambang S., Idrus Alwi, Marcellus S.K., Siti Setiati. Ilmu Penyakit Dalam FKUI. Ed.IV. Jakarta : FK UI. pp: 1392-5.

Soetojo. 2009. Inkontinensia Urin Perlu Penanganan Multi Disiplin. http://soetojo.blog.unair.ac.id/200 9/03/13/inkontinensia-urin-perlupenangananmulti-disiplin.

Somantri, B., 2015. Hubungan Indeks Massa Tubuh (Imt) Dengan Tekanan Darah Pada Lansia Di Puskesmas Melong Asih Cimahi. Jurnal Pendidikan Keperawatan Indonesia (JPKI) Vol 1, No 1 (2015).

Subak L.L., Whitcomb E., Shen H., Saxton J., Vittinghoff E., Brown JS. 2005. Weight Loss: A Novel and Effective Treatment For Urinary Incontinence. J Urol. 174(1):1905

Swanson J.G, Kaczorowski J., Skelly J., Finkelstein M. 2005. Urinary
Incontinence Common Problem Among Women Over 45. Canadian Family Physician. Vol 51. pp:84-5

Ulfah, R., 2016., Hubungan Indeks Massa Tubuh Dan Paritas Dengan Inkontinensia Urin Pada Perempuan Lanjut Usia Di Uptd Rumoh Seujahtra Geunaseh Sayang Banda Aceh. Banda Aceh : Fakultas Kedokteran Universitas Syiah Kuala, 2016.

Widyaningtyas, S.A., 2012. Hubungan Usia Menarche Dengan Obesitas Pada Remaja Putri Di Sma Theresiana 1 Semarang. Artikel Penelitian Program Studi Ilmu Gizi, Fakultas Kedokteran Universitas Diponegoro. 